\title{
森と鳥の生態学
}

\author{
江崎保男\# \\ 姫路工業大学自然・環境科学研究所／兵庫県立人之自然の博物館 $\mathbf{7} 669-1546$ 三田市弥 \\ 生が丘 6 丁目
}

\section{Ecology of Forests and Birds}

\begin{abstract}
Yasuo EZAKI \#
Himeji Institute of Technology/Museum of Nature and Human Activities, Hyogo, Yayoigaoka 6, Sanda, Hyogo 669-1546, Japan
\end{abstract}

\begin{abstract}
Why do so many specie of birds coexist in forests? Generally there will be three different answers to this question. The first answer is concerned with the diversity of vegetation structure: existence of various habitats for different species of birds. The second is concerned with primary production of forests. The high productivity of forests ensures a steady supply of resources necessary for survival and breeding of diverse bird species. The third is concerned with the complexity of biotic interactions among different species of organisms. The complex interactions consequently function to maintain the populations of diverse bird species in forests. Ecologists are required to explain the community and/or ecosystem process by organizing these three viewpoints: habitat, productivity and biotic interactions. The following three papers are contributions from speakers at a symposium held at the 2000 Annual Meeting of Ornithological Society of Japan. They review ecology of birds in forests or of forests with birds, sharing the viewpoints.
\end{abstract}

なぜある場所には特定の生物種が生息している のか，あるいは種の集団である特定の群集が成立 しているのか, そして別の場所には異なった生物 種あるいは群集が生息・成立しているのか,この 疑問に答えることは生態学の本質的な課題である. 種の絶減や生物多様性の減少が危俱され, 生態系 の保全が急務となっている今日, この課題は生態 学者にますます重くのしかかってきている.

ここでとりあげる森は地球上であっとあ複雑な 生態系のひとつである. 樹木が壮大な三次元空問 を作りあげ，そこに多種多様な生物種を住まわせ ていると同時に, 大量の有機物を生産し, これら の住人に直接・間接に豊富な食料を提供している.

当然のことながら, 森においては鳥の多様性も 高い.「なぜ森には多種多様な鳥が生息している
のか?」この問いに対する第 1 の答えは,「森の樹 木が作り出す複雑な三次元空間構造が多種多様な 生息場所（ハビタット）を鳥に提供するから」と いうあのであろう．性質の異なったいろいろな場 所があれば，それぞれに適応した多種多様な鳥が 共存可能というわけである. 第 2 の答えは,「こ れら多種多様な鳥の生存と繁殖を支えるだけの多 種多様でかつ大量の資源（餌や巣場所）が森の中 で生産されているから」というあのであろう，八 ビタットが存在していても餌や巣場所といった資 源がなければ鳥は生きていけないのである。第 3 の答えは,「多種多様な生物間に張りめぐらされ た生物間相互作用が適正に機能することによって 多種多様な鳥の個体群がそれぞれ維持されている から」というあのであろう.むろん，この八ビタッ

\# E-mail: ezaki@nat-museum.sanda.hyogo.jp 
卜・生産性・生物問相互作用の 3 者に着目する べきだという考えは, 森だけでなく, ありとあら ゆる生態系にあてはまるあのであり，この 3 者 をいかに有機的に関連づけて群集あるいは生態系 のありようを理解し説明するかが, 生態学の大き な目標のひとつだといっても差し支えないであろ う.

以下に続く 3 つの論文は, 北海道大学で開催 された日本鳥学会2000年度大会のシンボジゥム 「森と鳥の生態学」の講演者達からよせられたも のである.これらの講演者達はそれぞれ北海道・ 近幾地方・中部地方の森で, 鳥を中心にしながら あ他の生物群を含む群集あるいは生態系を対象と した精力的な調査を行っている研究者達である.

今回よせられた論文は各研究者の研究テーマの一 部が総説のかたちにまとめられたものである. 村 上は森のなかでも河川と結びつきの深い河畔林を とりあげ，河畔林の鳥の多様性にハビタット・生 産性・生物間相互作用のいずれむが関わっている ことを紹介している，また，河畔林は一般に面積
が小さいため, 森に隣接する河川や後背地の影響 を強く受けており，こういった場合には隣接する 他の景観要素む同時に評価する必要があることを 指摘している. 日野は, 森における生物間相互作 用を, 高次捕食者・種子散布者としての鳥が果た す機能を中心にしながらす他の生物が果たす機能 あ含めて, 広く一般的に紹介している. また, 森 の分断化などによる生物多様性の減少を単なる八 ビタットの喪失ととらえるだけでなく, 生物間相 互作用の変化の結果としてもとらえるべきである と述べている．堀田・江崎は森が鳥にもたらす重 要な資源のひとつである自然樹洞をとりあげ，こ の資源をめぐる種問の相互作用とこれに影響を与 える捕食, あるいは相互作用系全体についての研 究が進みはじめたことを紹介している.

これらの論文の編集・校閲にあたられた方々, 特に江口和洋編集委員長には大変お世話になった。 またシンポジゥムの開催にあたっては大会事務局 の方々にご配慮をいただいた。ここに深くお礼を 申し上げる. 